V. S. Morozova, V. A. Kashparov, S. Ye. Levchuk, A. O. Umanska, Ye. V. Bishchuk, L. M. Otreshko

National University of Life and Environmental Sciences of Ukraine, Kyiv

\title{
THE FUNCTIONAL STATE OF CELLULAR ANTIOXIDANT DEFENCE SYSTEM OF SHOOTS OF ARABIDOPSIS THALIANA EXPOSED TO THE CHRONIC IONIZING RADIATION IN THE CHORNOBYL EXCLUSION ZONE
}

The functional state of the cellular antioxidant defence system of shoots of Arabidopsis thaliana plants that grow in natural conditions in the areas of the Chornobyl Exclusion Zone with the values of the external dose rate of 0.45 , 0.61 , $1.05,4.81$ and $6.80 \mu \mathrm{Gy} / \mathrm{h}$ was evaluated. The decrease of the content of thiobarbituric acid reactive compounds in the shoots of Arabidopsis thaliana was revealed under the external dose rate of 4.81 and $6.80 \mu \mathrm{Gy} / \mathrm{h}$ by 38 and $48 \%$, respectively, compared to this parameter value under the external dose rate of $0.45 \mu \mathrm{Gy} / \mathrm{h}$. In the investigated samples the capacity of guaiacol peroxidase increases, catalase and ascorbate peroxidase decreases significantly with the increase of the external dose rate from 0.45 to $6.80 \mu \mathrm{Gy} / \mathrm{h}$. Probably, revealed changes in the functional state of the cellular antioxidant defence system of the shoots of Arabidopsis thaliana in the conditions of radioactive contamination are adaptive in nature.

Keywords: Arabidopsis thaliana, external dose rate, Chornobyl, cellular antioxidant defence system, lipid peroxidation, reactive oxygen species, enzymes.

\section{Introduction}

After the accident at the Chornobyl Nuclear Power Plant (NPP) in 1986 [1] and the Fukushima Daiichi NPP in 2011 [2] the population was evacuated from the most radioactively contaminated areas, and as a result the exclusion zones, where it would be impossible to live for people for a long time (people wouldn't be able to live in the $10-\mathrm{km}$ zone of the Chornobyl NPP for tens and hundreds of thousands of years), were formed [3]. In this regard, problems of the radiation protection of the environment after the nuclear and radiation accidents for the territories with relatively high levels of ionizing radiation for nonhuman biota, where people do not live permanently, have become actual [4 - 6].

In the researches directed on solving problems of the radiation protection of the environment after the nuclear and radiation accidents the International Commission on Radiological Protection [7] and the ERICA (Environmental Risks from Ionizing Contaminants: Assessment and management) European Project [8] recommend to use following reference species of plants: trees (pine tree), shrubs, grasses and herbs (wild grass). In contrast to trees, grass species is not clarified in these recommendations. At the same time Arabidopsis thaliana meets the requirements for the reference species of plants and has been recommended by the IAEA. In the first years after the Chornobyl accident, during 1986 1992, a number of studies devoted to radiobiological effects of the ionizing radiation in Arabidopsis thaliana of the Exclusion Zone under the external dose rate $0.2-2400 \mu \mathrm{Gy} / \mathrm{h}$ were carried out $[9,10]$.
Obtained data suggests that adaptation to ionizing radiation is a complex process involving epigenetic regulation of gene expression and genome stabilization that improves plants' resistance to environmental mutagens [10]. Reactive oxygen species (ROS) are involved in the epigenetic regulation processes in stress conditions, including ionizing radiation [11]. ROS can perform a signalling function during the adaptation to ionizing radiation in plants [12]. Signalling function of ROS can be implemented by the modifying proteins (as a result it changes protein structure and, therefore, modulate their function); by changing the redox potential of the redox-sensitive cellular components (glutathione system, ascorbic system, plastoquinone pool, thioredoxin etc.) [13]; and by the inducing gene expression via activation of transcription factors $[12,14]$.

ROS signalling function is implemented due to the functioning of the cellular antioxidant defence system. Adaptation to chronic ionizing radiation in plants can occur through the modulation of the functioning of cellular antioxidant defence system [12]. After reviewing the roles and functions of ROS in the transduction of intracellular signal the scientific interest in investigation of parameters of the prooxidant-antioxidant status of animal and plant organisms has increased [15]. Currently, there are numerous data on the effects of the different types of ionizing radiation at different doses on the functional state of the cellular antioxidant defence system [16 19], but this data is unstructured and multidirectional. As it has been recommended during the IAEA Chornobyl Forum [1], for a comprehensive study of

(C) V. S. Morozova, V. A. Kashparov, S. Ye. Levchuk, A. O. Umanska, Ye. V. Bishchuk, L. M. Otreshko, 2016 
the effects of chronic ionizing radiation on the functional state of the cellular antioxidant defence system of plants and in order to investigate the role of ROS in the adaptation of plants to ionizing radiation in natural conditions systematic, deep, fundamental researches of parameters of prooxidant-antioxidant status and epigenetic changes in reference species of plants of the Chornobyl Exclusion Zone under the different levels of radioactive contamination must be carried out.

The goal of this work is to evaluate the influence of chronic ionizing radiation with different values of the external dose rate on the functional state of cellular antioxidant defence system of shoots of Arabidopsis thaliana plants that grow in natural conditions in areas of the Chornobyl Exclusion Zone with different levels of radioactive contamination.

\section{Materials and methods}

\section{Sampling procedure}

The plants (Arabidopsis thaliana) were collected in the areas with different radionuclide contamination level of the Chornobyl Exclusion Zone (Table). Plants were washed with distilled water and quickly dried with filter paper. Shoots were separated and divided into portions of $100 \mathrm{mg}$ (approximately). Then collected samples were frozen in liquid nitrogen. All described procedures were conducted immediately. Samples were transported to the laboratory and stored for the following studies.

\section{The description of the areas of Arabidopsis thaliana sampling and radiation dose characteristics of the collected samples}

\begin{tabular}{|c|c|c|c|}
\hline \multirow{2}{*}{$\begin{array}{c}\text { Coordinates } \\
\text { of the areas }\end{array}$} & \multirow{2}{*}{$\begin{array}{c}\text { External } \\
\text { dose rate, } \\
\mu \mathrm{Gy} / \mathrm{h}\end{array}$} & \multicolumn{2}{|c|}{$\begin{array}{c}\text { Specific activity of samples } \\
\text { (mean } \pm \text { S.D.), } \mathrm{kBq} / \mathrm{kg} \mathrm{DW}\end{array}$} \\
\hline $\begin{array}{c}{ }^{90} \mathrm{Sr} \\
\text { E 31.39063 }\end{array}$ & 6.80 & $30 \pm 3$ & $2.3 \pm 0.2$ \\
\hline $\begin{array}{l}\text { N 51.38052 } \\
\text { E 30.02660 }\end{array}$ & 4.81 & $24 \pm 3$ & $1.8 \pm 0.2$ \\
\hline $\begin{array}{l}\text { N 51.34679 } \\
\text { E 30.12477 }\end{array}$ & 1.05 & $2.5 \pm 0.4$ & $0.18 \pm 0.02$ \\
\hline $\begin{array}{l}\text { N 51.34714 } \\
\text { E 30.12447 }\end{array}$ & 0.61 & $4.6 \pm 0.7$ & $0.24 \pm 0.03$ \\
\hline $\begin{array}{l}\text { N 51.39120 } \\
\text { E 30.05929 }\end{array}$ & 0.45 & $3.0 \pm 0.9$ & $0.2 \pm 0.1$ \\
\hline
\end{tabular}

\section{Radiation dose calculations}

During the sampling the value of the absorbed dose rate from the external exposure was obtained for each sampling site $(\mu \mathrm{Gy} / \mathrm{h})$. The absorbed dose rate is equal numerically to the equivalent dose rate $(\mu \mathrm{Sv} / \mathrm{h})$ that is measured in the field conditions with help of radiometer-dosimeter RKS-01
"STORA-TU" (ECOTEST, Ukraine).

Specific activities of ${ }^{137} \mathrm{Cs}$ and ${ }^{90} \mathrm{Sr}$ were measured in Arabidopsis thaliana samples collected in the areas with different levels of external exposure. Specific activity of ${ }^{137} \mathrm{Cs}$ was measured using a gammaspectrometer equipped with a high-purity germanium detector GEM-30185 and GammaVision32 software (EG\&G Ortec, USA). Specific activity of ${ }^{90} \mathrm{Sr}$ was determined by the radiochemical method [20]. ${ }^{90} \mathrm{Sr}$ activity was estimated through the measurement of its daughter product ${ }^{90} \mathrm{Y}$ using a beta-spectrometer SEB-70 (AKP, Ukraine). The values were expressed in $\mathrm{kBq}$ per $\mathrm{kg}$ of dry weight (DW).

The results of these researches, coordinates of the sampling sites and doses of the external exposure are presented in the Table.

\section{Analysis of Enzyme capacities}

Enzyme extraction was performed as described in [21, 22]. Frozen shoot tissue of $200 \mathrm{mg}$ was homogenized with $3 \mathrm{ml}$ of the extraction buffer containing $50 \mathrm{mM}$ sodium phosphate buffer $(\mathrm{pH}=7.8), 1 \mathrm{mM}$ EDTA, $1 \mathrm{mM}$ phenylmethylsulfonil fluoride, $1 \mathrm{mM}$ dithiotreitol, $8 \%$ polyvinylpyrrolidone, $0.1 \%$ Triton $\mathrm{X}-100$ in a cold mortar on an ice bath. The homogenate was centrifuged at $20000 \mathrm{~g}$ and $4{ }^{\circ} \mathrm{C}$ for $10 \mathrm{~min}$. The supernatant was used for the enzyme capacity measurement. The enzyme capacities were measured spectrophotometrically under non-limiting reaction conditions at $25{ }^{\circ} \mathrm{C}$. Catalase capacity was assayed at $240 \mathrm{~nm}$ according to the method of Begmeyer [23]. Ascorbate peroxidase and guaiacol peroxidase capacities was measured at $290 \mathrm{~nm}$ and $470 \mathrm{~nm}$, respectively, as described in [22]. Protein content in the extract was assayed by Bradford method using Coomassie Brilliant Blue G-250 [24].

\section{Content of TBA-reactive compounds}

The content of thiobarbituric acid reactive compounds (TBA-rc) was estimated according to method described in [21]. Plant tissue $(150 \mathrm{mg})$ was homogenized with $3 \mathrm{ml} 0.1 \%$ trichloroacetic acid (TCA) in a cold mortar on an ice bath. The homogenate was centrifuged at $20000 \mathrm{~g}$ and $4{ }^{\circ} \mathrm{C}$ for $10 \mathrm{~min}$. The supernatant was used for the reaction. The reaction mixture consisting of $0.5 \mathrm{ml}$ supernatant and $2 \mathrm{ml}$ TBA/TCA solution (0.5\% TBA in $20 \% \mathrm{TCA})$ was heated on a water bath at $95^{\circ} \mathrm{C}$ for $30 \mathrm{~min}$ and quickly cooled on an ice bath. After centrifugation at $20000 \mathrm{~g}$ for $10 \mathrm{~min}$, the absorbance of the supernatant was measured against deionized water at $532 \mathrm{~nm}$ and at $600 \mathrm{~nm}$ for the correction of unspecific absorbance. Also with this purpose, the absorbance of control and blank cuvette was measured at 532 and $600 \mathrm{~nm}$. Control consisted of $0.5 \mathrm{ml}$ super- 
natant and $2 \mathrm{ml} 20 \%$ TCA and was also centrifuged after the heating and then measured. Blanc consisted of $0.5 \mathrm{ml} 0.1 \%$ TCA and $2 \mathrm{ml}$ TBA/TCA solution. The TBA-rc content was calculated in $\mu$ mol per gram of fresh weight (FW), using millimolar extinction coefficient of $155 \mathrm{mM}^{-1} \cdot \mathrm{sm}^{-1}$.

\section{Statistical analysis}

All the analyses were repeated twice, each with three replications. Statistical analysis was performed using Student's $t$-test. $\mathrm{p} \leq 0.05$ was considered statistically significant. Results are presented as arithmetical mean \pm standard deviation (S.D.).

\section{Results and discussion}

The results of the enzyme capacities and TBA-rc content in the shoots of Arabidopsis thaliana which have been collected in the areas with different radionuclide contamination level of the Chornobyl Exclusion Zone are presented in Figure.

A decrease of the TBA-rc content in the shoots of Arabidopsis thaliana was revealed under the external dose rate of 4.81 and $6.80 \mu \mathrm{Gy} / \mathrm{h}$ by 38 and $48 \%$, respectively, compared to the samples under the external dose rate of $0.45 \mu \mathrm{Gy} / \mathrm{h}$ (see Figure). Revealed decrease of the TBA-rc content indicates the reduction of the intensity of lipid peroxidation processes, which can possibly be related to the activation of the cellular antioxidant defence system of the shoots of Arabidopsis thaliana in the conditions of the radiation contamination.

An increase in the guaiacol peroxidase capacity was found with the increase of the external dose rate (see Figure). In the shoots of Arabidopsis thaliana the guaiacol peroxidase capacity under the external dose rate of $1.05 ; 4.81$ and $6.80 \mu \mathrm{Gy} / \mathrm{h}$ is $1.8 ; 3.1$ and 3.3 times greater, respectively, than this parameter value under the external dose rate of $0.45 \mu \mathrm{Gy} / \mathrm{h}$. This increase in the guaiacol peroxidase capacity also could indicate the activation of the cellular antioxidant defence system of the shoots of Arabidopsis thaliana in the conditions of the radiation contamination.

The results of the research of the catalase and ascorbate peroxidase capacities are also presented in Figure. In the shoots of Arabidopsis thaliana the catalase capacity decreases by 31,33 and $35 \%$ under the external dose rate of $1.05,4.81$ and $6.80 \mu \mathrm{Gy} / \mathrm{h}$, respectively, compared to the samples under the external dose rate of $0.45 \mu \mathrm{Gy} / \mathrm{h}$. In the researched samples the ascorbate peroxidase capacity under the external dose rate of $0.61 ; 4.81$ and $6.80 \mu \mathrm{Gy} / \mathrm{h}$ is $1.4,1.7$ and 3.1 times lower, respectively, than this one under the external dose rate of $0.45 \mu \mathrm{Gy} / \mathrm{h}$.
Perhaps, the role of signalling molecule of hydrogen peroxide [15] is a reason of the decrease of the catalase and ascorbate peroxidase capacities with the increase of the external dose rate in the shoots of Arabidopsis thaliana. For this reason a definite controlled level of hydrogen peroxide may be provided in the plant cells in the amount which is necessary for the intracellular signal transduction in order to activate adaptation processes, including modulation of the cellular antioxidant defence system.

The values of the internal dose rate, which were calculated using specific activity of ${ }^{137} \mathrm{Cs}$ and ${ }^{90} \mathrm{Sr}$ according to [25], convergent to the values of the external dose rate (see Table). It should be noted that the internal dose rate varies in different periods of the growing season, because of the specific activity of radionuclides can change during the growing season and differs in different organs of plants. For this reason, obtained results were discussed taking into account the values of the external dose rate only. And in this regard, for correct estimation of the internal dose rate/accumulated dose during further researches it is planned to investigate the dynamics of the specific activities of radionuclides in different organs of Arabidopsis thaliana during the growing season.

\section{Conclusions}

Revealed reduction of the intensity of lipid peroxidation processes and the increase of the guaiacol peroxidase capacity may indicate the activation of the cellular antioxidant defence system of the shoots of Arabidopsis thaliana in the conditions of the radiation contamination. The decrease of the catalase and ascorbate peroxidase capacities may be caused by the signal function of hydrogen peroxide, because of the certain tonal level of hydrogen peroxide may be also provided by the reduction of the capacities of enzymes that are responsible for the neutralization of these species of ROS.

Thus, the changes in the functional state of the cellular antioxidant defence system in the conditions of the radiation contamination are directed toward the adaptation of the organism of Arabidopsis thaliana to the radiation influence. However, for comprehensive analysis of the functional state of the cellular antioxidant defence system in the conditions of radioactive contamination further researches of both enzymatic and non-enzymatic antioxidant defence mechanisms of cellular antioxidant defence system of different organs of reference species of plants, which grow in the areas of the Exclusion Zone with different levels of radioactive contamination must be performed. 

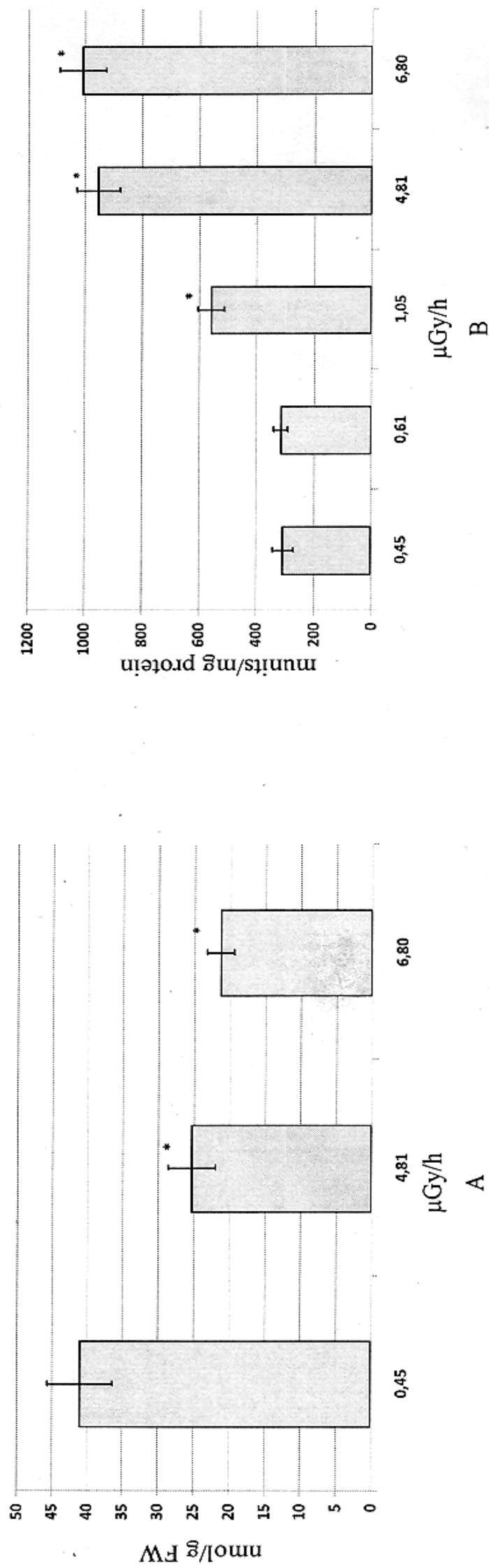

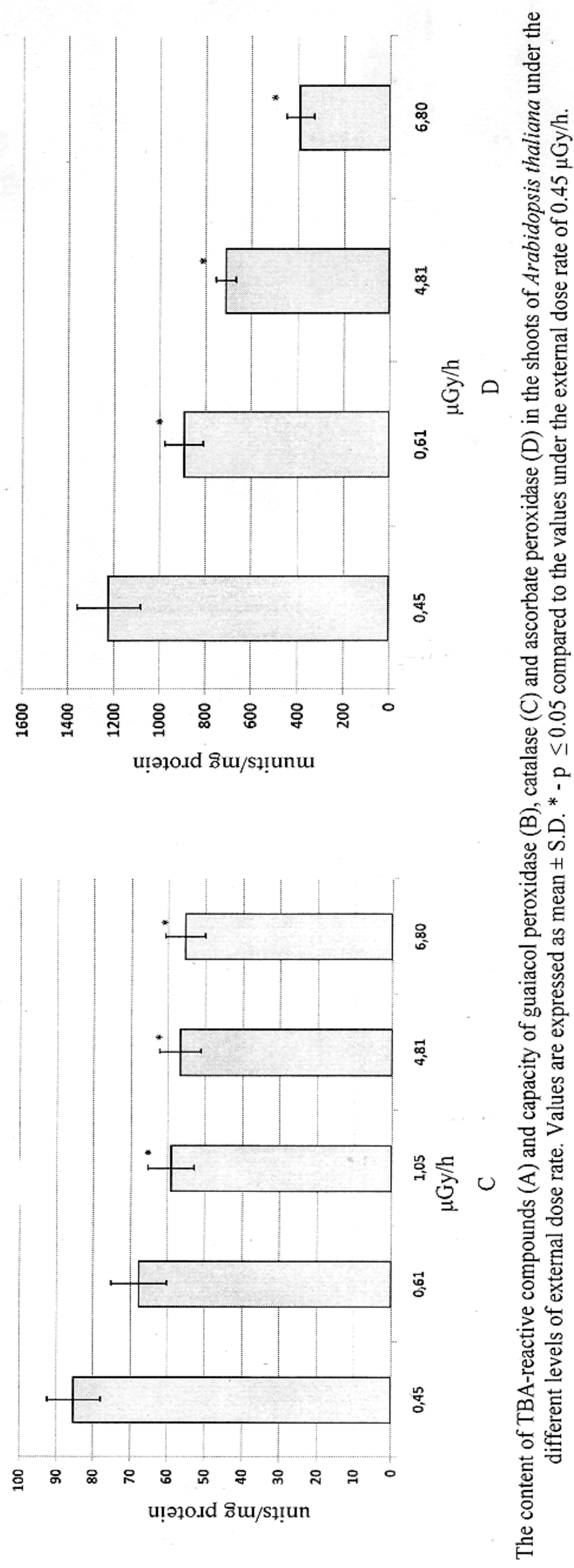


The research was performed as part of the scientific research work "Scientific monitoring of the radiobiological effects of the chronic ionizing radiation on the reference plant species in the areas radio- actively contaminated by Chornobyl NPP" and international COMET (Coordination and implementation of a pan-European instrument for radioecology) project.

\section{REFERENCES}

1. Environmental consequences of the Chernobyl accident and their remediation: twenty years of experience: report of the Chernobyl forum expert group "Environment" / Ed. By L. Anspaugh and M. Balonov. - Vienna: International Atomic Energy Agency, 2011. - $180 \mathrm{p}$.

2. The Fukushima Daiichi accident. - Vienna: International Atomic Energy Agency, 2015. - 1254 p.

3. Fesenko S.V., Alexakhin R.M., Geras'kin S.A. et al. Comparative radiation impact on biota and man in the area affected by the accident at the Chernobyl nuclear power plant // Journal of Environmental Radioactivity. - 2005. - Vol. 80. - P. 1 - 25.

4. Andersson P., Garnier-Laplace J., Beresford N.A. et al. Protection of the environment from ionising radiation in a regulatory context (project): proposed numerical benchmark values // Journal of Environmental Radioactivity. - 2009. - Vol. 100. - P. 1100 - 1108.

5. Pentreath R.J. Radioecology, radiobiology, and radiological protection: frameworks and fractures // Journal of Environmental Radioactivity. - 2009. Vol. 100. - P. 1019 - 1026.

6. Geras'kin S.A., Fesenko S.V., Alexakhin R.M. Effects of non-human species irradiation after the Chernobyl NPP accident // Environment International. - 2008. Vol. 34. - P. 880 - 897.

7. Environmental Protection: the Concept and Use of Reference Animals and Plants // The International Commission on Radiological Protection, ICRP Publication 108, Elsevier, 2008. - 242 p.

8. Brown J.E., Alfonso B., Avila R. et al. The ERICA Tool // Journal of Environmental Radioactivity. 2008. - Vol. 99 - P. 1371 - 1383.

9. Abramov V.I., Fedorenko O.M., Shevshenko V.A. Genetic consequences of radioactive contamination for population of Arabidopsis // The Science of the Total Environmental. - 1992. - Vol. 112. - P. 19 - 28.

10. Kovalchuk I., Abramov V., Pogribny I., Kovalchuk $O$. Molecular Aspects of Plant Adaptation to Life in the Chernobyl Zone // Plant Physiol. - 2004. - Vol. 135. P. 357 - 363.

11. Baird A-M., O'Byrne K.J., Gray S.G. Reactive Oxygen Species and Reactive Nitrogen Species in Epigenetic Modifications // Systems Biology of Free Radicals and Antioxidants / Ed. By I. Laher. - Springer Berlin Heidelberg, 2014. - Part 1. - P. 437 - 455.

12. Grodzynsky D.M., Gusha M.I., Dmitriev O.P. et al. Radiobiological effects of chronic ionizing radiation in the zone affected by the Chernobyl accident. - Kyiv: Nauk. Dumka, 2008. - 373 p. (Ukr)

13. Spadaro D., Yun B.-W., Spoel S.H. et al. The Redox Switch: Dynamic Regulation of Protein Function by Cysteine Modifications // Physiol. Plant. - 2010. Vol. 138. - P. 360 - 371.

14. Kreslavski V.D., Los D.A., Allakhverdiev S.I., Kuz- netsov Vl.V. Signalling role of reactive oxygen species in plants under stress // Russian Journal of Plant Physiology. - 2012. - Vol. 59. - P. 163 - 178. (Rus)

15. Kolupaev Y.Y., Oboznyi A.I. Reactive oxygen species and antioxidant system in the cross-action adaptation of plants to abiotic stressors // Newsletter of V. V. Dokuchaev Kharkiv National Agrarian University. 2013. - Vol. 3. - P. 18 -31. (Ukr)

16. Kolomiytseva I.K. Nonmonotonic of the dose-effect dependence at low doses of ionizing radiation // Radiatsionnaia biologiia, radioecologiia. - 2003. Vol. 43. - P. 179 - 181. (Rus)

17. Ren J., Liu L., Jin X.L., Fu L., Ding Z.C. Physiological and morphological responses induced by $\alpha$ particle radiation on Arabidopsis thaliana embryos // Genetics and Molecular Research. - 2014. - Vol. 13. P. 9569 - 9577.

18. Vandenhove H., Vanhoudt N., Cuypers A. et al. Lifecycle chronic gamma exposure of Arabidopsis thaliana induces growth effects but no discernable effects on oxidative stress pathways // Plant Physiology Biochemistry. - 2010. - Vol. 48. - P. 778 - 786.

19. Vanhoudt N., Horemans N., Wannijn J. et al. Primary stress responses in Arabidopsis thaliana exposed to gamma radiation // Journal of Environmental Radioactivity. - 2014. - Vol. 129. - P. 1 - 6.

20. Guidelines for determination of strontium- 90 and cesium-137 in soils and plants. - Moskva: CINAO, 1985. - 46 p. (Rus)

21. Vanhoudt N., Cuypers A., Horemans N., Remans T. et al. Unraveling uranium induced oxidative stress related responses in Arabidopsis thaliana seedlings. Part II: responses in the leaves and general conclusions // Journal of Environmental Radioactivity. 2011. - Vol. 102. - P. 638 - 645.

22. Venisse J-S., Gullner G., Brisset M-N. Evidence for the involvement of an oxidative stress in the initiation of infection of pear by Erwinia amylovora // Plant Physiology. - 2001. - Vol. 125. - P. 2164 - 2172.

23. Bergmeyer H.U., Gawehn K., Grassl M. Enzymes as biochemical reagents // Methods of Enzymatic Analysis / Ed. by H. U. Bergmeyer. - New York: Academic Press, 1974. - P. 425 - 522.

24. Bradford M.M. A rapid and sensitive method for the quantitation of microgram quantities of protein utilizing the principle of protein dye binding // Analytical Biochemistry. - 1976. - Vol. 72. - P. 248 - 254.

25. Savinskij A.K., Popov V.I., Kuljamin V.A. LET spectra and quality coefficients of incorporated radionuclides. - Moskva: Energoatomizdat, 1986. - 143 p. (Rus) 
В. С. Морозова, В. О. Кашпаров, С. С. Лсвчук, А. О. Уманська, С. В. Бішук, Л. М. Отрешко Національний університет біоресурсів і природокористування Украӥни, Київ

\section{ФУНКЦІОНАЛЬНИЙ СТАН СИСТЕМИ АНТИОКСИДАНТНОГО ЗАХИСТУ КЛІТИН ПАГОНІВ ARABIDOPSIS THALIANA ЗА ВПЛИВУ ХРОНІЧНОГО ІОНІЗУЮЧОГО ОПРОМІНЕННЯ В ЧОРНОБИЛЬСЬКІЙ ЗОНІ ВІДЧУЖЕННЯ}

Було проведено дослідження функціонального стану системи антиоксидантного захисту клітин пагонів Arabidopsis thaliana, що ростуть у природних умовах на ділянках чорнобильської зони відчуження із значенням потужності зовнішньої поглинутої дози $0,45,0,61,1,05,4,81$ та 6,80 мкГр/год. Установлено зниження вмісту тіобарбітурат-активних продуктів у пагонах Arabidopsis thaliana при значеннях потужності зовнішньої поглинутої дози 4,81 і 6,80 мкГр/год на 38 і 48 \% відповідно в порівнянні зі значенням даного показника при потужності поглинутої дози зовнішнього опромінення 0,45 мкГр/год. Активність гваяколпероксидази в досліджуваних зразках значно збільшується, а каталази та аскорбатпероксидази значно зменшується з ростом потужності поглинутої дози зовнішнього опромінення від 0,41 до 6.80 мкГр/год. Виявлені зміни функціональної активності системи антиоксидантного захисту клітин пагонів Arabidopsis thaliana за умов радіаційного забруднення, імовірно, носять адаптивний характер.

Ключові слова: Arabidopsis thaliana, потужність зовнішньої поглинутої дози, Чорнобиль, система антиоксидантного захисту клітин, пероксидне окиснення ліпідів, активні форми кисню, ферменти.

\section{В. С. Морозова, В. А. Кашпаров, С. Е. Левчук, А. А. Уманская, Е. В. Бищук, Л. Н. Отрешко}

Наичональный университет биоресурсов и природопользования Украины, Киев

\section{ФУНКЦИОНАЛЬНОЕ СОСТОЯНИЕ СИСТЕМЫ АНТИОКСИДАНТНОЙ ЗАЩИТЫ КЛЕТОК ПОБЕГОВ ARABIDOPSIS THALIANA ПРИ ВОЗДЕЙСТВИИ ХРОНИЧЕСКОГО ИОНИЗИРУЮЩЕГО ОБЛУЧЕНИЯ В ЧЕРНОБЫЛЬСКОЙ ЗОНЕ ОТЧУЖДЕНИЯ}

Было проведено исследование функционального состояния системы антиоксидантной защиты клеток побегов Arabidopsis thaliana, произрастающих в естественных условиях на участках чернобыльской зоны отчуждения со значениями мощности внешней поглощенной дозы 0,45, 0,61, 1,05, 4,81 и 6,80 мкГр/ч. Установлено снижение содержания тиобарбитурат-активных продуктов в побегах Arabidopsis thaliana при значениях мощности внешней поглощенной дозы 4,81 и 6,80 мкГр/ч на 38 и 48 \% соответственно по сравнению со значением данного показателя при мощности внешней поглощенной дозы 0,45 мкГр/ч. Активность гваяколпероксидазы в исследуемых образцах значительно увеличивается, а каталазы и аскорбатпероксидазы значительно уменьшается с ростом мощности внешней поглощенной дозы от 0,41 до 6,80 мкГр/ч. Обнаруженные изменения функциональной активности системы антиоксидантной защиты клеток побегов Arabidopsis thaliana в условиях радиационного загрязнения, вероятно, носят адаптивный характер.

Ключевые слова: Arabidopsis thaliana, мощность внешней поглощенной дозы, Чернобыль, система антиоксидантной защиты клеток, перекисное окисление липидов, активные формы кислорода, ферменты. 